\title{
REPRESENTASI GENDER PADA FILM TILIK MENURUT STUDI SEMIOTIK ROLAND BARTHES
}

\author{
Jonathan Adi Wijaya ${ }^{1}$, Antonius Denny Firmanto ${ }^{2}$ \\ jonathan.adi.w@gmail.com, ${ }^{2}$ rm deni@yahoo.com \\ ${ }^{1}$ Sekolah Tinggi Filsafat Teologi Widya Sasana
}

\section{Article Info}

Representation, Gender, Film Tilik, Media Literacy, Semiotic Roland Barthes

\begin{abstract}
Tilik is a Javanese short film that became a hot topic of conversation after its appearance on the YouTube channel. Tilik emphasizes a certain gender in each scene. As a result, Tilik is seen as perpetuating certain gender stereotypes. The researcher tries to find the meaning behind the gender used as the main character. With wider possibilities for meaning, the researcher also tries to find a deeper meaning that can be found in the Tilik film. Regarding the research objectives, this article poses the following problems: (1) Does Tilik Film perpetuate the stereotype of women? (2) What does the film say about its message? (3) What does the existence of the "truck" say about its function as a container of experience? The object of research is the context of the scenario, images, text, and scenes in the film. This article uses Roland Barthes's qualitative semiotics method. The results of this study indicate that Tilik does not perpetuate gender stereotypes by highlighting a particular gender. On the other hand, Tilik expresses the meaning of social relations in society, struggles in daily life, and the importance of digital literacy as a provision to participate in everyday life by using a certain gender.
\end{abstract}

Copyright (C) 2021 Interaksi: Jurnal Ilmu Komunikasi.

\section{PENDAHULUAN}

Film adalah salah satu bentuk media massa yang dekat dengan masyarakat. Dewasa ini, masyarakat mampu menikmati film hanya melalui laptop, bahkan gawai, tanpa harus menuju ke gedung bioskop. Film merupakan salah satu media audio visual untuk memberikan hiburan dan memudahkan penyampaian sebuah pesan. Film erat kaitannya dengan nilai-nilai budaya. Film menjadi jawaban atas waktu luang di luar jam kerja dan kebutuhan menikmati unsur budaya (Mudjiono, 2011; Wibowo, 2019)). Dengan film, manusia tidak hanya mampu mendapatkan hiburan tapi juga diajak berfantasi untuk sejenak melepaskan diri dari realita dan kesibukan.

Film mampu menarik aspek kognitif dan perasaan seseorang sehingga ia terlibat dan ikut merasakan apa yang dikisahkan dalam film (Vivian, 2008). Kekuatan ini membuat film mampu memberikan pengenalan akan sebuah budaya baru. Film mempunyai kekuatan untuk memperkenalkan budaya baru, mensosialisasikannya, atau bahkan menghilangkan budaya lama (Hariyani, 2018; Setyowati, 2013).

Film mampu meneruskan penilaian si pembuat film terhadap sebuah kelompok maupun isu hingga ke pembentukan stereotip (Perdana, 2014). Salah satu unsur penting dalam film untuk mewujudkan hal tersebut adalah alur cerita. Alur cerita mampu memindahkan ruang dan waktu sehingga penonton mampu merasakan situasi dan atmosfer yang diciptakan oleh si pembuat film.

Salah satu film yang mencuri perhatian dan sempat ramai menjadi bahan perbincangan di media sosial berjudul Tilik. Tilik adalah film pendek berbahasa Jawa yang menjadi bahan perbincangan setelah diunggah pada kanal YouTube pada 17 Agustus 2020. Per 12 Maret 2021, lebih dari 25 juta penonton telah melihat film tersebut di YouTube.

Wahyu Agung Prasetya, si pembuat film, menayangkan Tilik untuk yang pertama kali dalam acara Jogja-NETPAC Asian Film Festival (JAFF)

Corresponding Author:

${ }^{2}$ Prodi Filsafat Keilahian, Sekolah Tinggi Filsafat Teologi Widya Sasana

Jl. Terusan Rajabasa 2, Malang, Jawa Timur.

Email:2rm_deni@yahoo.com 
2018. Kemenarikan film pendek tampak dengan menonjolkan interaksi mereka yang terlibat dalam film tersebut. Pembuat film Tilik mampu memindahkan realitas kehidupan ke dalam media audio visual. Ia juga mampu memasukkan refleksi masyarakat ke dalam filmnya. Apa yang ditampilkan di film menggambarkan permenungan si pembuat film mengenai kehidupan sosial suatu masyarakat.

Jumlah penonton Tilik di YouTube tidak menghalangi munculnya kritikan. Budi Irwanto berpendapat bahwa film Tilik memiliki bias gender (Irawanto, 2020). Menurut Irawanto, film Tilik memberi stereotip kepada perempuan sebagai mereka yang suka bergosip. Lalu, penampilan pemeran film menyiratkan kesan misogini atau kebencian kepada perempuan dari si pembuat film. Hal tersebut tampak dengan cara mengangkat gagasan bahwa semua perempuan memiliki kebiasaan bergosip yang dipandang sebagai perilaku buruk. Akhirnya, film Tilik memberi kesan menyetujui perilaku suka menyebarkan hoaks (kabar bohong).

Tanggapan kritikus mengenai bias gender dalam sebuah film bukanlah hal yang baru. Ada beberapa peneliti yang juga menggunakan perspektif gender dalam mengulas sebuah film. Hasil penelitian Wibowo terhadap film Siti menyatakan bahwa si pembuat film Siti menampilkan perempuan Jawa sebagai pribadi yang tabah, kuat, dan tetap tegar berjuang melawan kehidupan. Namun, ia juga mengangkat perempuan Jawa sebagai pribadi yang penurut dan pasrah dalam menghadapi kenyataan kehidupan (Wibowo, 2019). Hasil penelitian Perdana menyimpulkan bahwa si pembuat film Anna Karenina telah mengkonstruksi stereotip gender (Perdana, 2014). Pembuat film Anna Karenina mengangkat peran perempuan di wilayah domestic. Lalu, ia mempersepsi buruk perempuan yang meninggalkan bahtera perkawinannya. Akhirnya, film Anna Karenina menempatkan perempuan sebagai pribadi yang hidup dalam stigma dari masyarakat. Lebih lanjut, hasil penelitian Astuti menunjukkan bahwa media massa memang memiliki stereotipe terhadap perempuan (Astuti, 2016). Perempuan adalah objek pencitraan. Produk yang menampilkan paras cantik seorang perempuan dapat menggugah konsumen untuk menjadi sama dengan bintang atau modelnya dengan cara membeli produk yang ditawarkan melalui media massa. Dalam hal ini, realitas kefisikan dari perempuan menjadi bahan eksploitasi.

Kesan yang muncul atas ulasan beberapa peneliti yang menyatakan bahwa film yang pemeran utamanya adalah perempuan memang memiliki bias gender memang dapat diterima. Namun, sebuah film akan menampilkan pesannya sendiri sejak hari penyajian film tersebut kepada publik. Publik dapat mengkonstruksi pesan yang mungkin bukan seperti yang dimaksudkan oleh si pembuat film. Dengan asumsi tersebut, peneliti berusaha untuk mencari makna yang lebih dalam yang dapat ditemukan dalam film Tilik. Berkenaan dengan hal tersebut, artikel ini mengangkat masalah: (1) Apakah ketenaran film tersebut menghadirkan pesan yang aktual dan relevan? (2) Apa pesan yang bermakna yang dapat ditemukan dalam film tersebut? (3) Apa arti keberadaan "truk" sebagai sebuah wadah pengalaman?

\section{KAJIAN PUSTAKA}

\section{Metodologi}

Objek kajian dari artikel ini adalah film Tilik. Metode yang digunakan untuk menelaah film ini adalah metode semiotika yang memusatkan perhatian kepada tanda (Wibowo, 2013). Film merupakan bidang kajian bagi paara analisis semiotika karena film menyajikan tanda (Mudjiono, 2011). Tanda memberi atau menyampaikan pesan. Sekumpulan tanda dapat membentuk sistem yang seluruh komponennya bekerja sama untuk mencapai sebuah makna tertentu atau efek tertentu bagi audiennya.

Dalam studi ini, keseluruhan isi film merupakan data penelitian. Karena itu, peneliti mengobservasi setting, peristiwa, dan percakapan dalam film untuk menemukan tanda yang bermakna. Percakapan atau peristiwa dalam film Tilik yang bertujuan menyampaikan pesan tidak akan dimaknai secara berbeda jika para pemeran dalam cerita memang sudah berhasil membentuk pokok makna cerita.

Lalu, peneliti menganalisis dan menafsirkan makna tanda dengan menggunakan pendekatan semiotika Roland Barthes (Santosa, 2013; Wibowo, 2013). Barthes menyatakan bahwa semiotika menempatkan 
audien atau pembaca sebagai pelaku utama pembangun makna (Santosa, 2013). Audien menerima pesan melalui dua tahapan, yaitu tahapan denotatif dan tahapan konotatif.

Denotasi adalah pemaknaan tahap pertama. Hubungan denotatif adalah hubungan antara ekspresi dan konten dari suatu tanda pada sebuah realitas eksternal. Makna denotatif sebuah tanda adalah apa yang tampak atau dapat diindrai oleh panca indra.

Konotasi adalah pemaknaan tahap kedua. Hubungan konotatif adalah interaksi yang terjadi ketika tanda bertemu dengan perasaan atau emosi dari pembaca dan nilai-nilai budayanya. Makna konotatif adalah pemberian makna dari sebuah tanda menurut konteks yang melingkupinya (Setyowati, 2013).

Contoh penggunaan makna denotatif dan konotatif adalah peristiwa upacara bendera. Sekelompok orang yang berbaris rapi menghormat ke arah bendera berkibar merujuk ke makna denotatif upacara bendera bagi yang menyaksikan peristiwa itu. Sikap sempurna dan penghormatan ketika bendera dinaikkan merujuk ke makna konotatif kesetiaan kepada tanah air, penghormatan kepada perjuangan pahlawan bangsa, atau juga bermakna kerelaan berkurban bagi nusa dan bangsa.

\section{Kajian Konseptual}

\section{Kajian Semiotika dalam Film}

Film Tilik termasuk dalam film cerita. Film cerita merupakan narasi mengenai kehidupan manusia. Aspek dramatis yang menyentuh emosi penonton memperkuat atau memperjelas pesan yang hendak disampaikan. Karena itu, film cerita biasanya bertolak dari eksplorasi konflik dalam suatu kisah, misalnya konflik seseorang dengan dirinya sendiri, dengan sesamanya, atau dengan lingkungan sosialnya. Plot kejadian-kejadian dalam film menunjukkan konflik atau krisis tersebut secara visual. Apa saja yang dapat dipikirkan dapat divisualkan (Mudjiono, 2011).

Karakter kebudayaan membawa warna kehidupan orang yang terlibat di dalamnya. Sesungguhnya pendukung kebudayaan itu bukan manusia seorang diri melainkan masyarakat seluruhnya. Oleh karena itu, manusia itu lahir, hidup, berkarya dan bersatu dengan orang lain. Hal itu merupakan eksistensi hidup manusia itu sendiri. Ini menandakan sebuah persatuan yang diungkapkan melalui banyak tanda.

Tanda denotatif yang muncul dalam sebuah tampilan memiliki arti konotatif sejauh audien memiliki relasi dengan realitas hidup sehari-hari. Latar yang tampil dalam film Tilik adalah praksis hidup sehari-hari manusia ada dalam budaya. Pemaknaan manusia mendapat pengaruh dari latar belakang budaya yang membentuk karakter dan bahasa yang digunakan (Setyowati, 2013).

Keberadaan Perspektif Gender dan Munculnya Stereotip dalam Film

Kata "gender" berarti konsep mengenai status, fungsi, peran ideal, dan tanggung jawab suatu individu yang dihasilkan oleh budaya dimana yang bersangkutan hidup (Megawati, 2017). Perspektif gender muncul sebagai hasil dari proses-proses sosial yang ada di dalam masyarakat, terutama berkenaan dengan pembagian tugas antara pria dan wanita.

Masyarakat mengidentikkan gender maskulin dengan kepriaan dan gender feminin dengan kewanitaan (Wibowo, 2019; Sutorini et al., 2019). Menurut masyarakat, maskulinitas bersifat kuat, jantan, berani dan rasional. Sifat feminin memiliki ciri-ciri lemah lembut, cantik, lebih banyak menggunakan emosi.

Masyarakat percaya bahwa peran perempuan adalah sebagai seorang feminin dan peran pria sebagai seorang yang maskulin. Namun, dapat ditemukan bahwa ada pria yang memiliki sifat lebih emosional, keibuan dan lembut. Begitu pula sebaliknya, ada perempuan yang memiliki keberanian layaknya laki-laki, kuat dan lebih rasional. Hal tersebut menunjukkan bahwa perspektif gender dapat berubah sesuai dengan kebudayaan dan lingkungan masyarakat yang mengitari hidup seseorang.

Perspektif gender merupakan hasil dari proses pembentukan diri oleh sosial dan kultural. Dengan demikian perspektif gender memuat konsep masyarakat mengenai norma ideal pria dan wanita. Dalam hal inilah bias gender dapat muncul jika menye- 
but bahwa seseorang dianggap maskulin jika dia badannya berotot dan terbiasa berolahraga. Sedangkan, seseorang yang dianggap feminin erat dikaitkan dengan omong kosong dan kebiasaan bergosip.

Stereotip adalah pemberian label pada seseorang atau sekelompok orang. Stereotip merupakan hasil yang didapatkan dari orang lain tentang sesuatu dan bukan dari diri sendiri yang bersangkutan atau masyarakat secara langsung (Saguni, 2020). Stereotip muncul sebagai konsekuensi dari sebuah penilaian. Seseorang yang mudah menghakimi akan dengan mudah pula untuk menilai orang. Tak jarang, banyak orang yang percaya dengan stereotip meski mereka tidak ikut mengalami. Stereotip juga merupakan produk sebuah budaya maupun lingkungan. Stereotip terbentuk dalam empat cara (Vivian, 2008). Cara pertama adalah pemberian gambaran yang terlalu sederhana pada anggota kelompok; gambaran dari anggota kelompok ini disamakan dengan perilaku anggota lain sehingga dianggap memiliki tipe yang sama. Cara kedua adalah bahwa stereotip terkadang otentik, tetapi sering kali tidak berdasar. Stereotip biasanya muncul karena seseorang tidak memiliki pemahaman terhadap objek stereotip tersebut, misalnya stereotip etnik. Familiaritas biasanya menghilangkan stereotip etnik ini. Cara ketiga adalah bahwa stereotip membujuk seseorang agar terpengaruh oleh persepsi dan ingatan seseorang tentang orang lain. Cara keempat adalah pengkambinghitaman.

Stereotip gender menjadi satu hal yang banyak sekali menjadi perbincangan. Stereotip sering kali bernada negatif dan identik dengan dugaan, perundungan maupun diskriminasi. Lingkungan yang memiliki budaya matriarki menampilkan stereotip perempuan yang bersifat superior. Padahal, stereotip yang umum beredar di masyarakat adalah laki-laki sebagai pihak yang lebih superior. Hal ini disebut dengan stereotip gender. Dengan demikian, stereotip gender dapat dinyatakan sebagai sebuah pemberian sifat tertentu dan penilaian tertentu pada orang lain yang sifatnya subjektif berdasarkan jenis kelamin yang dimiliki (Saguni, 2020).

\section{TEMUAN DAN DISKUSI}

"Tilik" diambil dari bahasa Jawa yang artinya "menjenguk". Tilik merupakan aktivitas yang biasa dilakukan oleh warga yang masih dilakukan hingga sekarang jika ada salah satu warga yang sakit. Tilik mengambil latar cerita sebuah perjalanan dengan menggunakan truk. Penumpang truk adalah sekelompok perempuan akan menjenguk $\mathrm{Bu}$ Lurah yang sedang sakit di rumah sakit di kota.

Tokoh Tilik adalah Bu Tejo yang menjadi pusat perhatian. Bu Tejo digambarkan sebagai sosok seorang perempuan paruh baya yang gemar bergosip. $\mathrm{Bu}$ Tejo membicarakan seorang perempuan muda yang bernama Dian. Selain itu, Bu Tejo juga mudah percaya pada sebuah berita tanpa merasa perlu untuk memverifikasinya.

Yu Ning, Yu Tri, dan Yu Sam adalah penanggap Bu Tejo. Yu Tri ditampilkan sebagai pihak yang provokatif yang setuju dengan $\mathrm{Bu}$ Tejo. Sebaliknya, Yu Sam menjadi pihak yang netral sepanjang film tersebut. Yu Sam memang ikut dalam pergunjingan dengan menimpali percakapan tanpa menunjukkan keberpihakan. Sedangkan Yu Ning tampil sebagai sosok perempuan yang tidak mudah percaya pada sebuah berita. Yu Ning berusaha melawan berita yang sedang disebarkan oleh $\mathrm{Bu}$ Tejo. Masalahnya adalah bahwa $\mathrm{Yu}$ Ning tidak memiliki dasar atau sumber yang cukup kuat kuat untuk menangkis atau menjauhkan penumpang truk dari gossip yang dibawa oleh $\mathrm{Bu}$ Tejo.

Perbincangan sebagai Peristiwa yang Menyingkap Pesan

Film ini dimulai dengan pembicaraan perempuan-perempuan di atas bak truk. Mereka telah mengumpulkan uang agar dapat mengunjungi $\mathrm{Bu}$ Lurah yang sedang sakit. Meski tidak dinyatakan secara langsung jika mereka berasal dari desa, namun percakapan mengenai kondisi desa menunjukkan bahwa mereka berasal dari desa.

Denotasi yang tampak pada film adalah gambaran mengenai sebuah perjalanan yang tampak dari awal hingga akhir cerita. Makna konotatif dari perjalanan menuju ke kota adalah bahwa hidup itu selalu bergerak. Pergerakan itu memuat masa-masa 
untuk berhenti sejenak untuk menunaikan kewajiban, menghibur diri atau membuat keputusan dalam sebuah rangkaian. Berhentinya truk di tengah perjalanan karena mogok bukan berarti perjalanan telah selesai. Selain itu usaha untuk menjenguk $\mathrm{Bu}$ Lurah dengan menaiki truk menunjukkan bahwa kehidupan itu memerlukan aneka upaya atau perjuangan yang tidak mudah.

\section{Tabel 1 Contoh Percakapan Di Jalan}

\begin{tabular}{ll}
\hline Percakapan & Pemaknaan \\
\hline Yu Tejo : Lho, iya & Perempuan tampil sebagai \\
bener. Makanya, Yu. & sosok yang tidak mau \\
menerima informasi mentah- \\
Yu Ning : Oala.. Kalian & mentah. \\
ini ngalah-ngalahin & \\
wartawan aja, deh. & \\
Sampe ngurusin seluk- & \\
beluk hidup orang lain. & \\
Sampe kaya gitu. & \\
Yu Ning : Tapi semuan- & Perempuan ditampilkan diri \\
ya belum tentu bener lo & sebagai sosok perempuan \\
Bu Tejo. Berita dari & yang belajar dari kebenaran. \\
internet itu harus dicek & Namun, kebenaran yang \\
dulu, nggak cuma disampaikan tidak mendapat- \\
ditelen mentah-mentah. & kan tanggapan bahkan terge- \\
Inget nggak, warga desa & ser oleh sebuah isu yang \\
kita dulu pernah ada baru. \\
yang ketipu obat herbal
\end{tabular}

Ibu-ibu sepanjang perjalanan membicarakan perempuan lain. Adegan ini menampilkan kesan jika perempuan memiliki kesenangan untuk bergunjing. Tokoh Bu Tejo menampilkan kesan tersebut. Peran Bu Tejolah yang menyebabkan masyarakat memandang sosok $\mathrm{Bu}$ Tejo sebagai perempuan yang suka bergunjing.

Makna konotatif dari proses perbincangan dalam film Tilik mengangkat aspek relasionalitas manusia. Manusia pada kodratnya adalah pribadi yang relasional. Manusia dalam hidupnya itu saling bergantung antara satu dengan yang lain. Sebagai makhluk yang berelasi maka manusia itu hidup dalam lingkup dunia yang tak terbatas. Dalam hal ini manusia tidak dapat dibatasi oleh hal-hal lain untuk membangun suatu kehidupan bersama yang harmonis. Tentu keharmonisan dalam hidup bersama menjadi fondasi untuk saling melengkapi dalam segala kekurangan yang dimiliki manusia.

Kebiasaan gosip sebagai proses dari keseharian hidup mencampurkan mana informasi yang benar dan mana informasi yang tidak benar atau yang bersifat opini. Keluasan wawasan pengetahuan, tingkat pendidikan, atau muatan emosi dalam menanggapi objek percakapan akan mempengaruhi proses gosip tersebut. Dari dirinya, gosip merupakan upaya anggota masyarakat untuk menselaraskan opini pribadi dengan kesadaran normatif masyarakat. Gosip muncul karena anggota masyarakat merasa ada hal yang terjadi di luar kewajaran sehari-hari kehidupan mereka. Dapat dikatakan bahwa gosip adalah perbincangan mengkritisi sebuah kenyataan yang terjadi di tengahtengah mereka. Percakapan dalam film Tilik menunjukkan bahwa para peserta perbincangan ada dalam relasi.

Tidak dapat dipungkiri bahwa manusia dalam sejarah pengungkapan eksistensinya merupakan makhluk yang relasional. Akal budi manusia mendorong manusia untuk tidak pernah berhenti memikirkan lintasan perjalanan hidupnya sehari-hari. Seiring dengan pengungkapan eksistensinya sebagai makhluk yang senantiasa berpikir, manusia selalu membutuhkan subyek di luar dirinya. Tidak pernah manusia mampu berpikir dari dan untuk dirinya sendiri. Ia senantiasa membutuhkan subyek yang lainnya (Pasi, 2020).

Kesadaran di atas menunjukkan bahwa manusia membutuhkan satu relasi dalam hidupnya. Contoh yang dapat diberikan adalah keberadaan pasangan suami-isteri. Kehendak untuk membangun sebuah keluarga tentu didasari adanya satu relasi yang intim, komitmen untuk hidup bersama-sama dalam relasi yang intim tersebut. Contoh sederhana tersebut mengatakan bahwa pada hakikatnya manusia dalam pengungkapan eksistensi dirinya tidak pernah sifatnya yang tidak relasional. Ia tetap membutuhkan sesamanya yang lain, sebagai tempat baginya mengungkapkan cara berelasinya.

Ada begitu banyak muatan dari relasi yang dilakukan manusia. Ketika manusia berelasi, sesungguhnya dapat dibedakan bentuk relasi yang ia jalani. Ada yang relasinya intim sebagai relasi cinta, 
ada pula relasinya yang sebatas profesi karena pekerjaan. Di samping itu ada yang relasinya sifatnya sosial karena hidup dalam satu tatanan masyarakat luas. Macam-macam bentuk relasi ini menjadi indikasi bahwa tidak ada sehari pun yang dilewatkan manusia tanpa mengungkapkan relasi kehidupannya dengan yang lainnya. Relasi menjadi hal yang begitu mendasari perjalanan hidup seseorang. Tanpa relasi, sekiranya eksistensi manusia menjadi sesuatu hal yang sulit untuk dipahami.

Kesadaran untuk membangun sebuah relasi, tentu didasari dari kemampuan akal budi dalam berpikir. Maka dengan sendirinya, setiap orang dapat menentukan bentuk relasi yang ia kerjakan setiap hari sesuai dengan kebutuhan hidupnya. Relasi yang dibangun setiap hari, tentu harus didasarkan pada kesadaran yang bebas. Bebas dalam memilih dan menentukan kepada siapa saja ia mau mengungkapkan relasi tersebut. Relasi yang baik tentu didasari pada kebebasan dalam menjalaninya.

\section{Kesadaran Literasi Sebagai Pesan Dari Film Tilik}

Film Tilik menampilkan asumsi bahwa kegiatan yang dilakukan oleh para perempuan jika sedang bersama adalah berbicara. Kianata berpendapat bahwa keseluruhan yang terjadi dalam pembicaraan adalah proses berkomunikasi di tengah masyarakat (Kianata, 2021).

Adegan yang menunjukkan ketidakpercayaan Yu Ning terhadap berita dari Bu Tejo menyatakan bahwa ada perempuan yang tidak suka berbicara buruk mengenai diri orang lain. Sosok Yu Ning tampil sebagai orang yang selalu berusaha untuk meminta sebuah bukti atas isu yang dibicarakan. Muncul dalam percakapan mereka ungkapan "fitnah", "berita bohong," atau "kalau mau memberi informasi dicek dulu kebenarannya”.

$\mathrm{Yu}$ Ning tidak percaya begitu saja dengan informasi yang diterima. Yu Ning belajar dari pengalaman konkrit yang dialaminya dan mengajak perempuan lain untuk mengingat hal tersebut. Namun, Yu Ning tidak mendapat tanggapan. Bahkan, pernyataan $\mathrm{Yu}$ Ning dilupakan begitu saja oleh perempuan lain. Adegan bantuan terhadap seorang penumpang yang mabuk darat mengalihkan perhatian para penumpang dari apa yang disampaikan oleh Yu Ning.

Keberadaan di Yu Ning dan problematikanya menunjukkan bahwa teknologi digital telah merambah ruang publik pedesaan. Seseorang atau sekelompok orang yang dapat mengaksesnya dapat mengalami transformasi kultural dengan kehadiran teknologi. Topik yang dibicarakan dalam ruang publik pedesaan juga mengalami pergeseran dari hal-hal yang bersifat domestik menjadi pembicaraan mengenai "orang lain" yang ditemukan dalam media sosial.

Sosok perempuan yang menjadi ancaman terhadap ruang publik ibu-ibu tokoh dalam film ini berdasarkan keyakinan yang mereka dapatkan dari media sosial. Film ini berupaya memberikan peringatan kepada masyarakat agar jangan terlalu percaya pada berita-berita yang berseliweran di internet dan media sosial sebelum benar-benar memastikan kebenarannya. $\mathrm{Bu}$ Tejo yang mengambil rujukan media sosial menjadi contoh tentang perlunya menyaring sebuah berita. Berita yang menarik bagi seseorang belum tentu bermanfaat atau berguna bagi orang lain. Dapat terjadi bahwa penyebaran opini tersebut menjadi penyebaran hoaks atau merundung seseorang.

\section{Tabel 2 Contoh Percakapan Klarifikasi}

\begin{tabular}{|c|c|}
\hline Percakapan & Pemaknaan \\
\hline $\begin{array}{l}\text { Bu Tejo: ... Aku paling } \\
\text { nggak suka ya kalau ada } \\
\text { orang yang ngomongin } \\
\text { bapaknya anak-anak } \\
\text { kayak gitu. ... } \\
\text { Yu Ning: Oh, jadi.. kalau } \\
\text { Pak Tejo yang diomon- } \\
\text { gin, Bu Tejo ga terima? } \\
\text { Gitu kok ngomongin } \\
\text { Dian padahal nggak ada } \\
\text { buktinya.... }\end{array}$ & $\begin{array}{l}\text { Perempuan memiliki sifat } \\
\text { setia dan mau memper- } \\
\text { tahankan kebenaran yang } \\
\text { diyakini. Sosok Bu Tejo } \\
\text { bahkan ditunjukkan se- } \\
\text { bagai seorang istri yang } \\
\text { mati-matian membela } \\
\text { penilaian terhadap sua- } \\
\text { minya. }\end{array}$ \\
\hline $\begin{array}{l}\text { Yu Ning: Tapi kan infor- } \\
\text { masi dari Bu Tejo itu } \\
\text { nggak jelas sumbernya? } \\
\text { Cuma dari omongan- } \\
\text { omongan di Facebook } \\
\text { sama internet aja. }\end{array}$ & \\
\hline $\begin{array}{l}\text { Bu Tejo: Kok masih } \\
\text { ngeyel, sih. Informasi } \\
\text { dari internet itu konkrit, } \\
\text { ada fotonya, ada gam- } \\
\text { barnya. Aku ulangin } \\
\text { sekali lagi ya, }\end{array}$ & \\
\hline $\begin{array}{l}\text { Yu Ning: Aku ini cuma } \\
\text { pengen jaga-jaga aja. }\end{array}$ & \\
\hline
\end{tabular}


Film Tilik menyampaikan pendapat bahwa literasi atau melek huruf tidak hanya sekedar kemampuan dalam hal membaca, menulis, dan berhitung saja. Literasi terkait juga pada pengetahuan dan keterampilan seseorang untuk dapat berpikir kritis, menemukan solusi, bersifat komunikatif, dan aktif dalam kehidupan bermasyarakat.

Literasi dalam konteks film Tilik berarti sebagai kemampuan khalayak sebagai pembaca untuk memilah-milah isi pesan media massa dalam konteks komunikasi massa. Literasi sebagai persoalan film Tilik mengetengahkan konsep personal locus, struktur pengetahuan, dan skill (Mudjiono, 2011; Vivian, 2008).

Personal locus adalah kendali individu terhadap informasi. Personal locus tersebut tampak dalam sosok Yu Ning juga memberikan gambaran bahwa perempuan selalu belajar dari pengalaman yang telah dilewati untuk mencapai sebuah kebenaran. Sementara struktur pengetahuan berupa seperangkat informasi yang terorganisasi dalam pikiran. Dalam menyaring informasi, individu memerlukan struktur informasi yang kuat. Sedangkan skill merupakan alat yang digunakan untuk meningkatkan kecakapan literasi.

Sosok $\mathrm{Yu}$ Ning yang bersikeras mengingatkan $\mathrm{Bu}$ Tejo menampilkan keberadaan masyarakat bijak yang tidak menelan informasi mentah -mentah tanpa mengetahui keakuratan sumbernya. Lalu, Yu Ning yang menyuarakan pendapatnya tanpa ragu mengekspresikan dorongan kepada anggota masyarakat untuk kritis terhadap semua hal yang terjadi di sekitarnya. Dalam keadaan nyata, terutama bagi masyarakat Jawa Tengah dalam hal ini Yogyakarta, keterusterangan dalam menyampaikan isi hati bukanlah hal yang lumrah. Sebagian besar dari mereka cenderung menahannya, hingga waktu yang dirasa tepat. Kalimat yang digunakan juga tidak langsung pada permasalahan, cenderung berputar-putar sebelum masuk pada pembicaraan utama.

$\mathrm{Bu}$ Tejo dan $\mathrm{Yu}$ Ning juga menjadi simbol jika perempuan selalu berusaha mempertahankan argumen dan apa yang mereka miliki. Hal ini tampak dari adegan adu mulut antara Yu Ning dan $\mathrm{Bu}$ Tejo. Bu Tejo yang tersinggung dengan ucapan Yu Ning tentang uang penghasilan suaminya pun berusaha membela suaminya. Yu Ning sendiri berusaha untuk membela
Dian karena tidak adanya bukti yang pasti. Yu Ning dan $\mathrm{Bu}$ Tejo berusaha membela apa yang mereka anggap benar.

Terlepas dari kebenaran hal yang dipertahankan, hal ini menunjukkan adanya kesetiaan dan keteguhan dalam diri perempuan. Terlebih pada sosok Bu Tejo yang membela suaminya. Yu Ning pun tetap teguh dengan pendiriannya. Adapun hal ini menunjukkan sosok Yu Ning yang meminta bukti yang yang jelas dan valid atas sebuah isu. Walaupun, Yu Ning sendiri juga tidak bisa menyangkal dengan memberikan bukti yang mematahkan argumen $\mathrm{Bu}$ Tejo.

Adegan adu mulut tersebut berhenti karena truk yang dinaiki tiba-tiba berhenti. Truk berhenti karena ada polisi yang menghentikan perjalanan truk. Polisi menyatakan bahwa ada penyalahgunaan fungsi truk. Truk tidak diizinkan untuk mengangkut orang.

Yu Ning dan $\mathrm{Bu}$ Tejo berhenti adu mulut mereka. Mereka berusaha untuk bernegosiasi agar tidak terkena tilang. Adegan diinterpretasikan oleh penulis bahwa perempuan juga ditunjukkan mampu meredam egoisme mereka untuk melawan suatu hal yang menghalangi perjalanan mereka, meski memiliki kepentingan masing-masing.

Yu Ning yang tidak segan-segan beradu pendapat dengan $\mathrm{Bu}$ Tejo yang status sosialnya lebih tinggi menampilkan gagasan kesetaraan. Kesetaraan tersebut tampak dalam keberanian para penumpang untuk mengutarakan pendapatnya, walau Yu Ning tidak seterbuka Bu Tejo. Bu Tejo dan Yu Ning adalah karakter utama yang membahas tentang berita bohong tentang kehidupan Dian. Kedua-duanya merasa benar dan membeberkan segala argumentasinya. Namun, di akhir cerita, sutradara memberikan kejutan bahwa Dian memang memiliki relasi dengan Pak Lurah. Relasi tersebut bukan relasi tidak wajar karena Pak Lurah berstatus sebagai duda. Adegan Dian yang duduk di dalam mobil bersama Pak Lurah menunjukkan bahwa perdebatan $\mathrm{Bu}$ Tejo dan $\mathrm{Yu}$ Ning tidak mempunyai dasar. 


\section{Tabel 3 Contoh Percakapan Isi Hati}

\begin{tabular}{ll}
\hline Percakapan & Pemaknaan \\
\hline Dian: Mas, sepertinya aku & Adanya gambaran yang \\
sudah tak sanggup lagi & kuat tentang perempuan \\
hidup sembunyi seperti & yang mampu menahan \\
ini. Kapan ya, Mas, & perasaan mereka untuk \\
Fikri bisa menerima & sebuah kebaikan tanpa \\
kalau bapaknya mau & ingin adanya pihak yang \\
menikah lagi? & disakiti. \\
Minto: Tenangkanlah & \\
pikiranmu. Kamu harus \\
sabar. Percayalah pa- \\
daku.
\end{tabular}

Dian, yang menjadi bahan obrolan perempuan lain, berbicara dengan Pak Lurah Minto, ayah Fikri, pada akhir film. Adegan ini secara denotasi menggambarkan sosok Dian yang meminta Pak Lurah Minto untuk menikahinya. Pernikahan tersebut akan mengakhiri semua pembicaraan yang ada di sekitar dirinya. Sosok Dian menjadi simbol bahwa perempuan mampu bertahan dan menahan diri untuk kebaikan banyak orang (Wibowo, 2019). Pemilihan ending ini secara tidak langsung menyatakan bahwa perempuan memiliki kemampuan untuk mempertimbangkan segala sesuatu secara menyeluruh. Perempuan yang bersifat merawat dan memelihara tampak dalam sosok Dian yang tidak mau melukai hati orang lain untuk keputusan yang diambilnya.

Keberadaan "Truk" Sebagai Sebuah Wadah
Pengalaman

Representasi berarti menghadirkan. Representasi dapat berwujud kata, gambar, sekuen, cerita dan lain-lain yang mewakili ide, emosi, atau fakta (Wibowo, 2019). Representasi menyampaikan konsepkonsep yang telah ada dan dipahami secara kultural. Representasi juga dipandang sebagai suatu bentuk usaha dalam mengonstruksi baik makna maupun realitas. Dalam konteks penelitian ini, kehadiran tokohtokoh perempuan dalam hal ini menjadi sarana yang menggambarkan hidup masyarakat.

Truk dapat menggambarkan masyarakat. Bak truk merupakan wadah tempat dimana masyarakat mengikuti perjalanan truk. Macetnya truk dapat menggambarkan kemandegan yang terjadi dalam proses perjuangan masyarakat. Partisipasi dan kontribusi elemen masyarakat demi berjalannya truk merupakan pesan film Tilik yang perlu dicermati. Penumpang yang mau ambil bagian dalam perjuangan untuk meraih menjaga kewarasan masyarakat (Banusu \& Firmanto, 2020). Masyarakat akan hidup normal jika tiap-tiap anggotanya mau ikut menggerakkan kehidupan masyarakatnya.

Perbincangan para perempuan di atas truk menggambarkan situasi sehari-hari masyarakat. Aneka topik kehidupan menjadi sarana anggota masyarakat untuk menjalin relasi dengan sesamanya. Adegan truk mogok menjadi adegan menarik karena tidak semua penumpang ikut mendorong truk tersebut agar truk tersebut dapat bergerak kembali. Ketidak-ikut sertaan mereka dapat ditafsirkan sebagai representasi dari mereka yang hanya membonceng perjuangan dan jerih lelah mereka yang ikut mendorong truk. Para pembonceng perjuangan ini mewakili mereka yang bersifat opportunis dan yang hanya mau menikmati hasil perjuangan orang lain (Siswati, 2019).

Penumpang yang tidak ikut ambil bagian dan hanya mengikuti dari belakang dapat pula ditafsirkan sebagai mereka yang memiliki agenda lain yang tersembunyi (Prastyanti, 2018). Adegan menunggu orang lain turun tangan dapat menggambarkan keberadaan dari mereka yang tidak memiliki kreativitas dalam memperjuangkan sesuatu dalam hidup. Ketika perjalanan hidup mogok, setiap orang tidak boleh hanya menunggu belas kasihan orang lain. Orang tidak boleh diam ketika hidupnya macet.

\section{Tabel 4 Contoh Percakapan Memotivasi}

\begin{tabular}{ll}
\hline Percakapan & Pemaknaan \\
\hline $\begin{array}{c}\text { Gotrek : wah, harus di- } \\
\text { dorong nih, Yu. }\end{array}$ & $\begin{array}{l}\text { Perempuan lebih banyak } \\
\text { digambarkan sebagai sosok }\end{array}$ \\
Yu Ning : Aduh... & yang mau berjuang dan \\
tidak berpangku tangan \\
$\begin{array}{l}\text { 1....... Ayo! Alham- } \\
\text { dulillah... }\end{array}$ & saja. \\
\hline
\end{tabular}

Makna konotatif "bak" truk bersumber dari fungsinya. Bak truk merupakan bak besar yang berada di belakang digunakan untuk mengangkut barang. Bak truk berupa kotak tertutup dan berpintu. Bak truk bukan hanya sekedar ilustrasi belaka. Bak truk merupakan cerminan kehidupan keseharian masyarakat Indonesia. Bak truk menggambarkan interaksi sosial antar individu di dalam masyarakat majemuk yang terdiri dari beragam suku Indonesia memiliki berbagai 
permasalahan yang kompleks (Pratama, 2013).

Perkembangan kepribadian individu pada masyarakat ini sering dihadapkan pada model-model perilaku yang suatu saat disangkal sedang saat yang lain disetujui oleh beberapa kelompok namun dicela oleh kelompok lainnya. Masyarakat Indonesia sebagai salah satu negara berkembang mempunyai ciri adanya perubahan yang sangat pesat dalam berbagai aspek kehidupan, seperti perubahan sistem ekonomi, politik, sosial dan sebagainya. Dalam kenyataan tidak ada satu pun gejala perubahan sosial yang tidak menimbulkan akibat terhadap kehidupan masyarakat setempat. Isu-isu tentang kemiskinan, perceraian, poligami, membuang sampah sembarangan, agama dan masih banyak lagi lainnya telah menjadi tema cerita di tengah kehidupan masyarakat (Pratama, 2013). Ekspresi para pelaku dalam film Tilik menyatakan apa yang terjadi di masyarakat.

Jalanan juga tidak lagi dipandang sebagai akses 'menuju' atau akses 'dari-ke' namun jalanan telah mendukung adanya paradigma definisi sosial yang mengakui manusia sebagai aktor yang kreatif dalam realitas sosialnya (Pratama, 2013). Penyajian kembali fragmen dalam kehidupan sosial masyarakat mewakili fenomena kehidupan bersosialisasi. Ungkapan dari gagasan yang diwakilinya akan sering muncul dalam bentuk sebuah dukungan, tolakan, kritikan, atau mungkin bisa saja hanya netral/tidak memihak.

\section{Tabel 5 Contoh Percakapan Memberi Solusi}

\begin{tabular}{ll}
\hline Percakapan & Pemaknaan \\
\hline Bu Tejo: Gimana Ibu-Ibu? & $\begin{array}{l}\text { Perempuan ditampilkan } \\
\text { sebagai sosok yang } \\
\text { Setuju, kan? }\end{array}$ \\
$\begin{array}{l}\text { Ibu-Ibu: Iya, jelas setuju! } \\
\text { mampu solusi di saat terjadi hal- } \\
\text { Ayo berangkat! }\end{array}$ & $\begin{array}{l}\text { hal di luar rencana. } \\
\text { Bu Tejo: Ya sudah Trek, }\end{array}$ \\
kita mampir Pasar Ber- \\
ingharjo, ya. Jadi orang \\
itu yang solutif gitu, lho. \\
Gotrek: Ayo berangkat!
\end{tabular}

Denotasi dalam adegan ini menunjukkan bahwa $\mathrm{Bu}$ Tejo memberikan solusi ketika ternyata $\mathrm{Bu}$ Lurah belum bisa dijenguk. Perempuan yang lain banyak yang kecewa karena tujuan mereka tidak tercapai. Bu Tejo pun memberikan usul untuk mampir ke pasar karena sudah terlanjur datang ke kota. Usul Bu
Tejo membuat perempuan yang lain mendapat hiburan dari kekecewaan mereka. Adegan ini dipahami oleh penulis bahwa perempuan lebih banyak yang merasa kecewa jika tujuannya tidak tercapai. Namun, di satu sisi sosok $\mathrm{Bu}$ Tejo juga menjadi simbol bahwa perempuan mampu memberikan solusi ketika perjalanan tidak sesuai dengan tujuan (Amin, 2017).

Nilai positif yang terkandung pada film tersebut adanya sifat gotong royong dan kepedulian masyarakat terhadap budaya menjenguk jika ada orang terdekat yang sakit, budaya menjenguk sudah menjadi tradisi turun menurun pada masyarakat, terlebih di daerah Jawa. Menjenguk orang sakit merupakan salah satu tumpuan yang dapat digunakan untuk mendukung seseorang dalam hidup bersosial. Kegiatan menjenguk orang sakit kerap didasari oleh rasa simpati seseorang terhadap sesamanya dan dilakukan dengan memberikan perhatian lebih kepada orang yang sedang dalam kondisi sakit, baik dirawat inap di Rumah Sakit atau istirahat di rumah.

Kebersamaan menjadi sesuatu yang sangat diinginkan oleh setiap orang. Entah kebersamaan dalam lingkup yang kecil misalnya; kebersamaan dengan orang tua dan sanak saudara dalam keluarga, kampung, atau pun bangsa dan negara dalam lingkup yang lebih luas (Amin, 2017). Dengan kebersamaan, orang merasa senasib dan sepenanggungan, saling berbagi, menyelesaikan masalah secara bersama, berjuang dan bahagia bersama. Ibarat lidi bila sebatang maka sangat mudah untuk dipatahkan, tetapi bila lidi-lidi itu dikumpulkan dalam jumlah yang banyak dan diikat menjadi satu kesatuan sehingga membentuk kebersamaan maka akan sangat sulit untuk dipatahkannya.

Demikian pula halnya dengan manusia. Jika mengandalkan diri sendiri dan terlalu yakin bahwa setiap masalah dapat diselesaikan sendiri, maka orang itu pasti gagal mewujudkannya karena dirinya dihantui rasa penat menahan, stres dan teralienasi (terasing) dengan dirinya sendiri (Pasi, 2020). Dalam keber samaan ada kesadaran akan pribadi (manusia) dan pribadi yang lain. Dalam kebersamaan juga ada kekuatan, sehinga kuat karena satu dalam keber samaan, dan pribadi satu karena kuat dalam keber 
samaan. Dalam kebersamaan ada semangat persaudaraan dan persahabatan untuk saling mengafirmasi (mengakui) dan menerima satu sama lain sebagai pribadi yang berharkat dan bermartabat, bujukan semangat untuk saling mengobjeksi, menegasi (mengingkari) dan meminggirkan yang lain (Abhipraya et al., 2021). Membina hubungan baik antara sesama dalam kebersamaan menjadi kunci sukses mengungkapkan diri manusia sebagai homo socius.

\section{KESIMPULAN}

Film Tilik merupakan sebuah film pendek yang memberi makna. Film ini bukan sekedar film yang mengangkat tema perempuan yang suka bergunjing. Latar yang sederhana tidak berarti bahwa pesannya juga sederhana. Kisah selama perjalanan menunjukkan bahwa masyarakat pedesaan telah berubah. Namun, perubahan mentalitas tidak menyertai perubahan sosio-kultural yang diakibatkan oleh keberadaan media sosial tersebut Meskipun mereka masih memperhatikan kebiasaan baik mengunjungi tetangga atau kerabat yang sakit atau yang sedang mengalami kesusahan, perangkat modern berupa gadget telah mempengaruhi cara mereka mempersepsi pengalaman hidup sehari-hari. Analisis yang dilakukan terhadap film Tilik dengan menggunakan metode semiotik Roland Barthes menemukan bahwa film Tilik tetap memandang bahwa percakapan dengan segala dinamikanya tetap menjadi unsur pembentuk kehidupan masyarakat. Lalu, film Tilik mendorong pemirsanya agar memiliki literasi media. Literasi media membantu masyarakat untuk tidak mudah bingung atau panik berkenaan dengan sebuah pemberitaan. Literasi media membantu masyarakat untuk tetap menemukan arah yang baik di tengah aneka macam informasi. Dan akhirnya, keberadaan "truk" menjadi gambaran dari masyarakat sebagai sebuah wadah pengalaman hidup bersama. Film Tilik menunjukkan sisi lain perempuan sebagai pribadi yang mau berjuang, tabah dan mampu berpikir jenih untuk memberi solusi.

\section{DAFTAR PUSTAKA}

Abhipraya, F. A., Khatami, M. I., \& El Muntaha, M. H. (2021). Representasi Relasi Kuasa Dalam Kelompok Masyarakat Pada Film Tilik. Jurnal Interaksi: Jurnal Ilmu Komunikasi, 5(1), 102116. https://doi.org/http://dx.doi.org/10.30596\% 2Finteraksi.v5i1.5340

Amin, M. A. S. (2017). Komunikasi Sebagai Penyebab Dan Solusi Konflik Sosial. Jurnal Common, 1(2), 101-108. https://doi.org/10.34010/ common.v1i2.573

Astuti, Y. D. (2016). Media Dan Gender (Studi Deskriptif Representasi Stereotipe Perempuan dalam Iklan di Televisi Swasta). Profetik, 9(2), 25-32. https://doi.org/https://doi.org/10.14421/ pjk.v9i2.1205

Banusu, Y. O., \& Firmanto, A. D. (2020). Kebahagiaan Dalam Ruang Keseharian Manusia. Forum, 49 (2), 51-61. https://doi.org/10.35312/ forum.v49i2.301

Hariyani, N. (2018). Analisis Semiotika Representasi Citra Perempuan Dalam Film Kartini. Jurnal Sosial, 19(1), 19-42.

Irawanto, B. (2020). Menilik Film Tilik. https:// budiirawanto.com/menilik-film-tilik/

Kianata, J. (2021). Representasi Kebiasaan Bergosip Dalam Film Pendek Tilik. Universitas Pelita Harapan.

Megawati, E. (2017). Media dan Gender (Studi Deskriptif Stereotyping Gender Pada Iklan Susu HiLo Teen). Jurnal Komunikasi Stikom Prosia, $12(2), 8-21$.

Mudjiono, Y. (2011). Kajian Semiotika dalam Film. Jurnal Ilmu Komunikasi, 1(1), 125-138. https:// doi.org/https://doi.org/10.15642/jik.2011.1.1.125 $-138$

Pasi, G. (2020). Relasionalitas "Aku" dan "Engkau" dalam Masyarakat Indonesia yang Majemuk sebagai Gambaran Relasionalitas Trinitas. Jurnal Studia Philosophica et Theologica, 20(2), 103126. https://doi.org/https://doi.org/10.35312/ 
spet.v20i2.189

Perdana, D. D. (2014). Stereotip Gender dalam Film Anna Karenina. Interaksi: Jurnal Ilmu Komunikasi, 3(2), pp 123-130. https:// doi.org/10.14710/interaksi.3.2.123-130

Prastyanti, S. (2018). Komunikasi, Partisipasi, dan Konflik dalam Pemberdayaan Masyarakat. Jurnal Ilmu Komunikasi Acta Diurna, 14(1), 6878. https://doi.org/https://doi. org/10.20884/1. actadiurna. 2018.14. 1.1143.

Pratama, N. W. A. (2013). Fenomena Di Balik Lukisan Bak Truk. Jurnal Rupa-Rupa, 2(2), 107-132.

Saguni, F. (2020). Dinamika Gender Dalam Masyarakat. Musawa: Journal for Gender Studies, 12(2), 207-227. https://doi.org/https:// doi.org/10.24239/msw.v12i2.667

Santosa, H. P. (2013). Sosok Calon Legislatif Lokal dalam Iklan-iklan Politik (Kajian Semiotika terhadap Iklan-iklan Politik Calon Legislatif Lokal di Media Massa Cetak Lokal Jawa Tengah). Interaksi: Jurnal Ilmu Komunikasi, 2 (2), 1-12. $\quad$ https://doi.org/https:// doi.org/10.14710/interaksi.2.2.104-116

Setyowati, U. (2013). Kajian Semiotika tentang Etika Komunikasi Anas Urbaningrum dalam Pengaruh Budaya Jawa. Interaksi: Jurnal Ilmu Komunikasi, 2(2), $\quad$ 82-89. $\quad$ https://doi.org/https:// doi.org/10.14710/interaksi.2.2.185-192

Siswati, S. (2019). Perilaku Oportunistik Penyusun Anggaran Dan Dampaknya Terhadap Pertumbuhan Ekonomi Di Indonesia. Jurnal Riset Manajemen Dan Bisnis, 13(2), 129-147. https:// doi.org/10.21460/jrmb.2018.132.311

Sutorini, M. P., Alif, M., \& Sarwani. (2019). Semiotika Gender dalam Film Brave. Jurnal ProTVF, 3(1), 101-112. https://doi.org/https://doi.org/10.24198/ ptvf.v3i1.21246

Vivian, J. (2008). Teori Komunikasi Massa. Kencana.

Wibowo, G. (2019). Representasi Perempuan dalam Film Siti. Jurnal Nyimak, 3(1), 47-59. https:// doi.org/http://dx.doi.org/10.31000/ nyimak.v3i1.1219

Wibowo, I. S. W. (2013). Semiotika Komunikasi Aplikasi Praktis Bagi Penelitian dan Skripsi Komunikasi. Mitra Wacana Media. 